\title{
Transformation of the Bryansk Paleosol in Microdepressions in the Center of the East European Forest-Steppe during the Maximum of Valdai Glaciation and in the Holocene
}

\author{
S. A. Sycheva ${ }^{a, *}$, P. R. Pushkina ${ }^{a}$, O. S. Khokhlova ${ }^{b}$, and P. A. Ukrainsky ${ }^{c}$ \\ ${ }^{a}$ Institute of Geography, Russian Academy of Sciences, Moscow, 119017 Russia \\ ${ }^{b}$ Institute of Physicochemical and Biological Problems in Soil Science, Russian Academy of Sciences, \\ Pushchino, Moscow region, 142290 Russia \\ ${ }^{c}$ Belgorod State National Research University, Belgorod, 308015 Russia \\ *e-mail: sychevasa@mail.ru \\ Received November 26, 2019; revised February 7, 2020; accepted February 26, 2020
}

\begin{abstract}
Recent and Late Pleistocene soils of the central forest-steppe in the East European Plain have been studied. The main objective of the work is to reveal changes in the properties of the Bryansk paleosol (final phase of MIS 3), one of the most important geosols of the Late Pleistocene. These changes could be induced by cryogenesis during the Valdai glaciation maximum (MIS 2) and by the Holocene pedogenesis (MIS 1) under different conditions of the modern microtopography. We have studied the catena of Holocene soils underlain by the Bryansk paleosol within a small closed depression in the Kazatskaya Steppe of the V.V. Alekhin Central Chernozemic Biospheric Reserve in Kursk oblast. The depression is supposedly the result of loess subsidence. Haplic Chernozems develop on the microelevation; Luvic Chernozems, on the microslope; and Luvic Chernozems (Stagnic), in the bottom of the depression. The upper humus horizons of the Holocene soils are similar in all parts of the microcatena. On the slopes and in the lower part of the microdepression, the Ah2 subhorizon is replaced by the AE horizon, and the Bk horizon becomes carbonatefree and turns into the Bt horizon. The change in the "normal" profile of the paleosol of the Bryansk Interstadial began already at the latest stages of its formation. The Bryansk soil was strongly deformed by cryogenic processes during the maximum of the Valdai glaciation (Vladimir cryogenic horizon). The secondary diagenesis of the Bryansk paleosol is associated with soil formation in the Holocene. Holocene soils are superimposed on the profile of the Bryansk paleosol, transforming it differently in various parts of the catena. On the microelevation, the diagenesis in the Holocene is regarded as minimal. The Bryansk paleosol is most transformed in the bottom of the microdepression.
\end{abstract}

Keywords: diagenesis, Chernozem, cryogenesis, Holocene, micromorphology

DOI: $10.1134 / \mathrm{S} 1064229320090173$

\section{INTRODUCTION}

The Bryansk paleosol is one of the two main stratigraphic soil levels of the Late Pleistocene. It has many temporal analogues that are developed in loess regions all over the world and have local names: the Lohner soil in Germany, the Stillfried B soil in Austria, the Denekamp soil in the Netherlands, the Pedocomplex I in the Czech Republic, the Surduk soil in Serbia, the Dubnovskaya soil in western Ukraine, the Vitacheskaya soil 3 in central and eastern Ukraine, the Iskitim pedocomplex in Western Siberia, the Osin pedocomplex in southeastern Siberia, the Farmdale in the United States, and other analogues $[2,3,8,10,12-15,20,21$, 23-27, 31-35, 37]. The radiocarbon age of the Bryansk paleosol is 25-33 ka BP (uncalibrated) [9, 13, 22, 36]. However, it does not cover the entire interval of the complex megainterstadial of the Late Pleistocene (66-25 ka BP).
The Bryansk paleosol formed only during the final warming stage of the Middle Valdai (Middle Valdai, Würm, Weichselian) megainterstadial (marine isotope stage MIS 3). This period was characterized by the leveled relief of elevated plains and the mitigation of severe periglacial conditions before the maximum of the last glaciation [5, 6, 8-10, 17, 19, 26, 38, 39].

In the periglacial and extraglacial regions of the East European Plain, the Bryansk paleosol is diagnosed univocally due to its bright morphotypic characteristics [5, 8, 9, 16]. A typical Bryansk paleosol has humus horizons in large cryogenic wedges and the calcareous horizon with elevated upper boundary between the wedges.

The genesis of the Bryansk paleosol is difficult to reconstruct. Its direct analogues are unknown among modern soils, since the conditions of the periglacial zone are not typical of the modern interglacial period. 


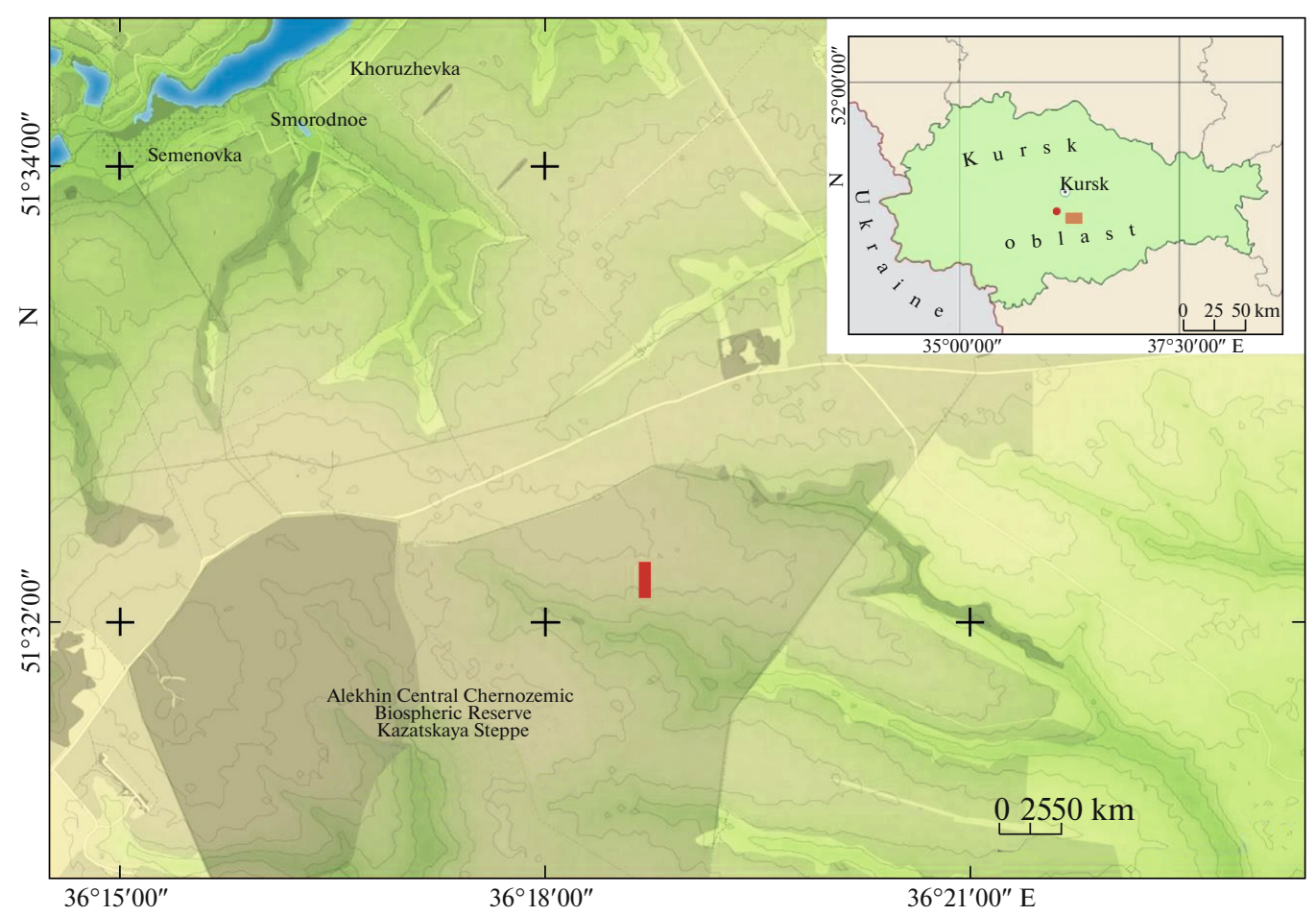

Fig. 1. The location of the study site. The Aleksandrovskii quarry is marked by the red dot near Kursk. The studied catena is marked by the red rectangle.

According to Morozova [13], the closest analogues of the Bryansk paleosol are permafrost-affected taiga and forest-steppe pale (palevye) soils in the continental regions of Central Yakutia. They have similar diagnostic features: ooidal structures, which may result from cryogenic coagulation, fulvate composition of humus, increased clay content, and gleyic features in the profile $[7,11]$.

The Bryansk paleosol acquired its bright morphotypic features as a result of not only soil formation during the period of the paleosol functioning but also of cryogenic processes (primary diagenesis) during the maximum of the Valdai glaciation (Vladimir cryogenic horizon), when the soil remained on the surface for a long time [36].

The Bryansk paleosol often lies at a depth of 1.5 to $5 \mathrm{~m}$. If it is of shallow occurrence, it is included in the profile of modern soils, being part of their parent material. In such cases, the Bryansk paleosol is exposed to the Holocene pedogenesis and undergoes new transformation (secondary diagenesis). The nature of the diagenetic changes depends on the genesis of modern soils and the position of the paleosol in the modern microrelief. The goal of this publication is to determine the interdependencies of macro- and micromorphological characteristics and some physicochemical properties of the Bryansk paleosol and the Holocene soil developed over it under different conditions of the modern microrelief.

\section{STUDY AREA}

In this study, the catena along the slope of one of the microdepressions in the Kazatskaya Steppe $\left(51^{\circ} 31^{\prime} 28^{\prime \prime} \mathrm{N}, 36^{\circ} 17^{\prime} 44^{\prime \prime}\right.$ E) was studied (Fig. 1). The Kazatskaya Steppe is one of the areas of the V.V. Alekhin Central Chernozemic Biospheric Reserve. The reserve is located in the southwest of the Central Russian Upland within the forest-steppe zone with moderately continental climate. Ivanov's hydrothermal coefficient is 1.0-1.3, which corresponds to optimal and slightly humid conditions. Summer is warm with more than $70 \%$ of the annual precipitation. Winter is relatively cold with a stable snow cover.

In the Kazatskaya Steppe, the zonal type of vegetation (automorphic herbaceous meadow steppes), which has almost disappeared in the European forest-steppe, is preserved. The species richness of herbs on the territory is very high (up to 120 species per $100 \mathrm{~m}^{2}$ ). There are 12 species of ancient relict plants that survived repeated glacial periods (glaciers have never covered this area). Such was the pristine steppe untouched by humans a thousand years ago. For a long time, this area was called the "Wild Field." Up to now, it is preserved in its pristine form and serves as a model of meadow steppes developing under conditions of sufficient atmospheric precipitation $(500-600 \mathrm{~mm} / \mathrm{yr})$ [15].

The Central Chernozemic Biospheric Reserve is one of the few forest-steppe areas that have survived in 
its primeval state, and where deep virgin chernozems are preserved. The thickness of the humus profile of Haplic Chernozems reaches $1.5-1.7 \mathrm{~m}$. The humus content in the top $10 \mathrm{~cm}$ of the soil is $9-12 \%$, and humus storage in the 1-m-deep layer is $540 \mathrm{t} / \mathrm{ha}$.

The microrelief of the Kazatskaya Steppe is characterized by numerous closed depressions (Fig. 2). These are small rounded or oval-shaped depressions with flat bottoms; they are often referred to as steppe saucers. They are randomly scattered on the surface of the steppe separately or in clusters. The diameter of the depressions reaches $30-50 \mathrm{~m}$ and more. Their depth does not exceed $1-1.5 \mathrm{~m}$. In the spring, snowmelt accumulates in the steppe saucers, so that $t$ temporary water pools can form in them. In summer, steppe saucers are distinguished by dark green color of their vegetation against the background yellowing grasses and gray feathergrass.

The origin of such depressions is still debatable. Suffosion-induced subsidence and thermokarst hypotheses of their genesis are most widely accepted. The suffosion-induced subsidence hypothesis suggests leaching of soluble salts and carbonates, lessivage (removal of clay particles), and soil compaction as mechanisms of significant subsidence of the initial loess volume in the bottom of the microdepressions. The second popular hypothesis of microdepression genesis suggests that cryogenic processes and formation of ice wedges took part during the loess accumulation. Later, a large mass of underground ice melted during thermokarst development in the Late Valdai period (MIS 2.1). Morphogenetic analysis of microdepressions and their sediments allows us to give preference to one or another hypothesis. For thermokarst, the presence of large pseudomorphs of the Late Pleistocene cryogenic period (Yaroslavl stage according to Velichko [4]) should be easily recognized in the sections. If they are absent, the thermokarst origin is excluded. Recently, the polygenetic nature of steppe saucers has been suggested; in fact, this concept implies different meanings: from the presence of different factors and processes in their formation to the multistage and asynchronous development.

Recently, the anthropogenic origin of microdepressions has been discussed [29, 30]. For microforms of such genesis, an indispensable condition is the disturbance of the natural soil profile as a result of human activity.

Long-term observations of small erosional landforms buried in loess and exposed in the Aleksandrovskii and other quarries within the Central Russian Upland, one of the authors established an impact of the buried Moscow-Mikulino paleorelief on the formation of surface microrelief and the modern soil cover pattern [17]. It was shown that many of the microdepressions visible in the modern relief are inherited from the buried Moscow-Mikulino erosional forms, since they developed within the upper parts of the slopes of these paleodepressions closest to the surface.

\section{OBJECTS AND METHODS}

Field study was conducted in 1986 at a specially protected reserve site, so that there were many difficulties in obtaining additional photographic materials. A typical microdepression (depression) was chosen near the border of the protected area. The soils were examined in a 4-m-deep and 19-m-long trench excavated along a radius of the closed microdepression (Fig. 2). The depth of the microdepression was 80$100 \mathrm{~cm}$, and its diameter was about $28-34 \mathrm{~m}$. It was impossible to excavate the central part of the microdepression because of the tall herb stand. However, the bottom of the microdepression could be observed in the trench. The width of the trench was limited by the width of the excavator bucket $(65 \mathrm{~cm})$. The narrowness of the trench made it impossible to take photographs of the examined profiles. However, a detailed drawing of the trench walls compensated for this drawback. A grid with cell size of $50 \mathrm{~cm}$ was drawn on the trench wall. Given the scale, the horizon boundaries, inclusions, and pedofeatures within each square of this grid were sketched on the graph paper (Figs. 3a and 3b).

The international system WRB-2015 was used to designate the horizons of modern chernozem and buried soils [28]. For a better understanding by Russian soil scientists, Russian symbols of soil horizons [11] are given in brackets [11]. Due to the insufficient development of the generally accepted classification of buried soils and pedocomplexes in soil science, the indexation of horizons of buried soils used in Quaternary paleogeography and paleopedology was applied. Brackets (or letter "b" according to WRB-2015) denote the horizons of buried soils included in the profile of the Holocene soil (as in our case) or in the profile of other paleosols (during the formation of pedocomplexes). If the paleosols were separated by loess, square brackets were not used, and the soil profiles located below the Holocene soils got usual symbols of horizons (without designation of their buried state).

The studied catena consisted of three sectors: eluvial on the microelevation $(1-8 \mathrm{~m})$, transitional on the slope $(8-13 \mathrm{~m})$, and accumulative at the bottom (13$19 \mathrm{~m}$ ). Soil description and sampling were performed on one trench wall along several vertical columns (analogues of soil pits) at points of 1.5, 5, 13, and $16 \mathrm{~m}$. Because of the polygonal pattern of the Bryansk paleosol, in some cases, sampling was performed from neighboring but different pedons: along a wedgeshaped crack in the microdepression and a bare circle on the microhigh.

To solve the problem posed in this paper, we used a standard set of methods for paleopedological research: macro- and micromorphological descriptions, sketches, major physicochemical analyses. The soil organic car- 


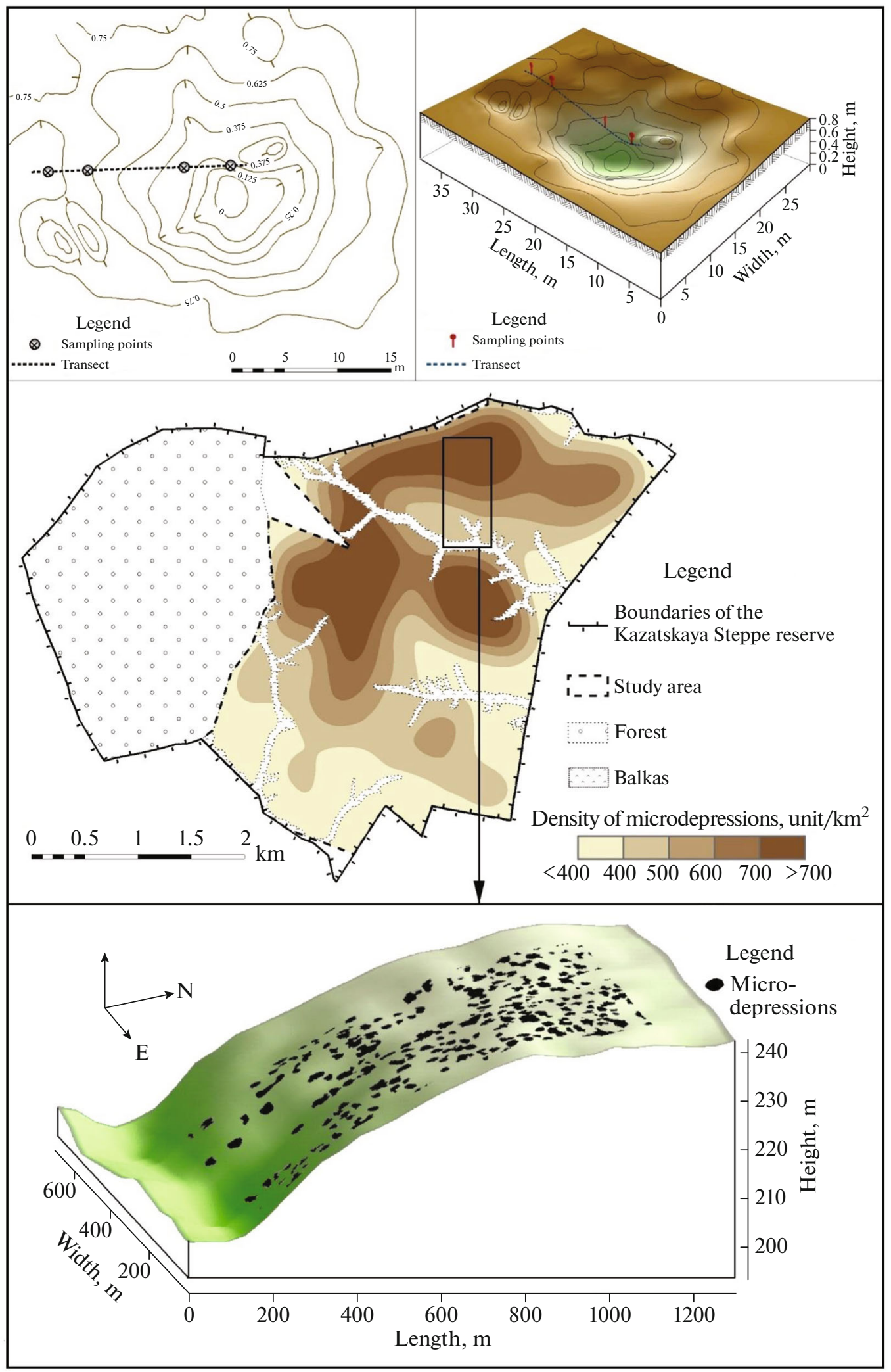

Fig. 2. The size and microrelief of the studied microdepression in the Kazatskaya steppe. 

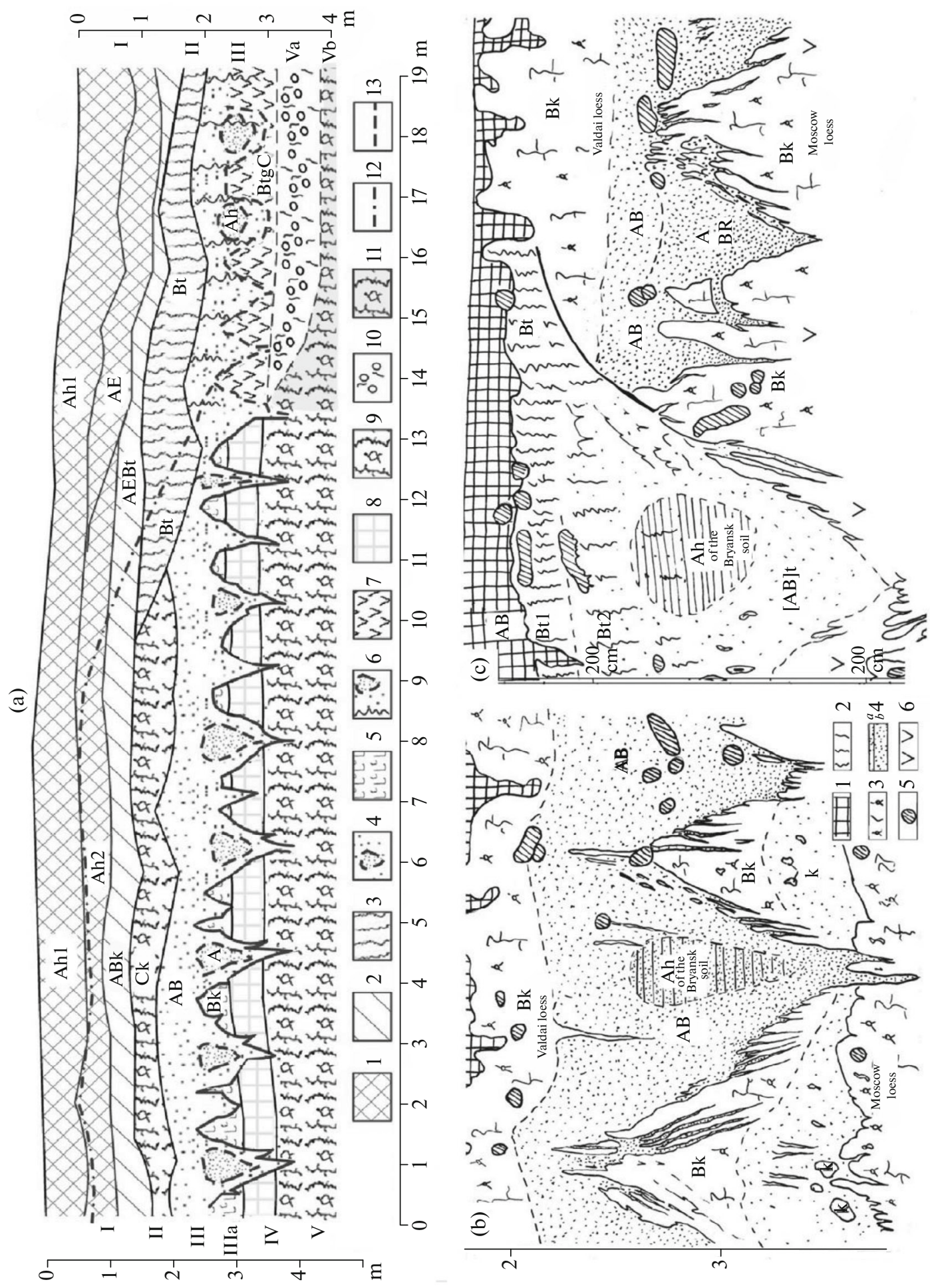

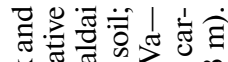

美

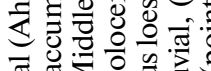

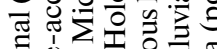

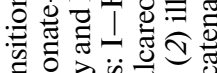

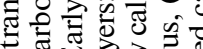

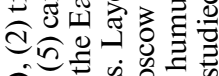

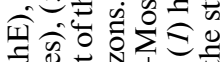

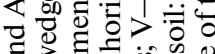

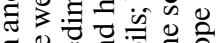

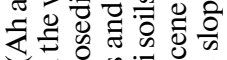

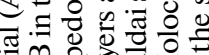

3

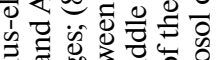

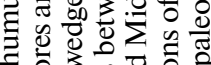

c)

응.

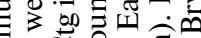

施

$\widehat{C} \Xi \mathrm{E}$ के

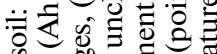

(1)

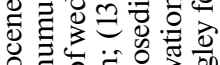

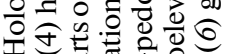

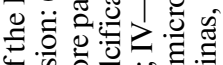

O

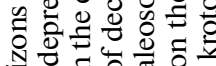

政

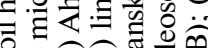

n

Dे

क人

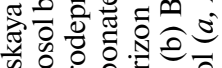

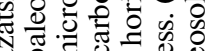

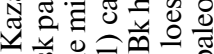

美

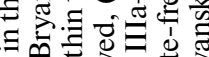

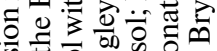

它

잉

次

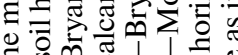

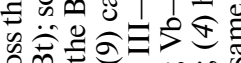

政论

可

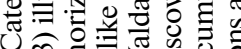

(1)

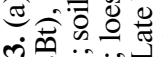

m.

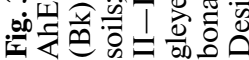


bon content was determined by the Tyurin method for all samples [1]. The manometric method was used for the determination of soil carbonates according to the amount of $\mathrm{CO}_{2}$ released in sealed vessels with rubber plugs, in which the reaction of soil samples with $10 \% \mathrm{HCl}$ solution took place. Thin sections were prepared from undisturbed soil samples (micromonoliths) taken from several vertical columns close to the places of bulk soil sampling. Thin sections were analyzed using a polarizing microscope CarlZeiss HBO 50 (Germany) at the Institute of Physicochemical and Biological Problems in Soil Science, Russian Academy of Sciences, Pushchino, Russia.

Radiocarbon dating of the Bryansk paleosol was not performed in this section. However, the dates were repeatedly obtained in the reference section of the Alexandrovskii quarry $15 \mathrm{~km}$ northwest of the Kazatskaya Steppe [20,36].

\section{RESULTS}

Macromorphological studies. The eluvial sector of the catena (points 1.5 and $5 \mathrm{~m}$ ).

Layer 1. Holocene soil-Haplic Chernozem [28] (Fig. 3a, Table 1).

Ah1 (A1), 0-50 cm. The upper part $(0-18 \mathrm{~cm})$ is the sod mat densely penetrated by plant roots. Dark gray heavy loam, fine angular blocky-granular structure, moderately compact, with bleached coarse silt particles on ped faces. In the lower part $(30-50 \mathrm{~cm})$, the aggregation degree of loam is higher. Intraped material (IPM) is homogeneous. The boundary is distinct according to changes in the IPM color.

Ah2 (AB), 50-100 cm. Brownish dark gray heavy loam, uneven in color; the IPM is homogeneous. Coarse prismatic-columnar structure. The peds are covered with dull humus-clay coatings with bright powdery carbonates on their surface.

ABk (ABca), 100-170 cm. Brown-gray heavy loam. The IPM is of uneven color. Columnar-angular blocky structure. Large aggregates break up into fine and medium angular and platy aggregates. There are many krotovinas and coprolites. Powdery carbonates are dispersed in the soil mass; there are also whitish carbonate coatings on ped faces. The lower boundary is disturbed by abundant krotovinas.

The humus profile (horizons $\mathrm{Ah}+\mathrm{AB}+\mathrm{ABk}$ ) has a thickness of $150 \mathrm{~cm}$ to $195 \mathrm{~cm}$.

Layer 2. Valdai loess, BCk (BCca), 170-210 cm. Light brown silty clay loam; effervescent; with columnar-prismatic structure. Vertical ped faces are covered by fragmental brown clayey coatings. The soil mass is porous and disturbed by earth burrowers: 12 krotovinas per $1 \mathrm{~m}^{2}$. The boundary is slightly wavy and diffuse with vertical veins of $1.5-2 \mathrm{~cm}$ in thickness extending downwards to a depth of $250 \mathrm{~cm}$.
Layer 3. Bryansk paleosol (Figs. 3a and 3b), 210$290 \mathrm{~cm}$. The horizons $A h(A 1)$ and $A B$ are found inside the wedge-shaped cryogenic deformation (wedges of 100-120 cm in width in their upper part appear every $100-150 \mathrm{~cm}$ ). The height of the wedges is 130 to $170 \mathrm{~cm}$. Wedge-shaped structures end with a series of small humus streaks that can be traced down to a depth of 360-400 cm from the surface. The internal configuration of postcryogenic structures is heterogeneous. The wedges contain denser pear-shaped cores (Ah horizon). The width of the cores is $50-60 \mathrm{~cm}$ in the upper part and 5-6 $\mathrm{cm}$ in the lower part, and their height is $0.8-1.0 \mathrm{~m}$. The cores are brownish pale-yellow with grayish tint; heavy loamy (with the heaviest texture), dense, and more humified; there are abundant $\mathrm{Mn}-\mathrm{Fe}$ nodules and gleyed mottles. The IPM is unevenly colored with humus. There are dark brownish dull clayey coatings; the structure is ooidal. The edge zones of the wedges ( $\mathrm{AB}$ horizon) consist of dense bright brown loam; it is heterogeneous in color, microporous, finely fissured, with Mn concentrations, calcitic tubules, and ancient earthworm casts filled with darker humified loam. The main feature of this subhorizon is its microheterogeneity because of the presence of abundant earthworm casts and ooids.

Layer 3a. Bk (Bca), 240-290 cm. Light yellow silt loam; effervescent; carbonates are represented by loose silt-size calcite grains mixed with the mineral material. The most homogeneous carbonate material is found along the boundaries of wedge-shaped structures; in the dry state, it has a whitish color. In the upper part, at the base of the wedges, the Bk horizon appears like mottles in horizontal section. At the lower boundary, the loam is gleyed and contains Mn concentrations and black very fine veins from the A horizon of the Bryansk paleosol.

Layer 4. Pedosediment, $290-350 \mathrm{~cm}$. Redeposited material of more ancient (Middle and Early Valdai) soils transformed in the course of cryogenesis and additional sedimentation. It is represented by the grayish pale yellow silt loam with a brownish gray tint. It is heterogeneous in color with mottles of brown loam and with grayish, rusty, and humified veins. There are Mn concentrations, tiny calcitic nodules, and krotovinas filled with the underlying whitish pale yellow loam. The layer is dissected by the wedge-shaped structures of the Bryansk paleosol and has a trapezoidal form. Abrupt wavy boundary broken by subvertical attests to changes in the deposition of sediments: two loess horizons belong to different glacial periods (Valdai and Moscow glaciations).

Layer 5. Moscow loess, 350-580 cm. Sandy loam of whitish pale yellow color; loesslike; effervescent; with numerous $\mathrm{Mn}-\mathrm{Fe}$ concentrations. 
Table 1. Morphological description of the eluvial and accumulative sectors of the studied catena

\begin{tabular}{|c|c|c|c|}
\hline \multirow{4}{*}{ Layer } & \multirow{4}{*}{ Parameter } & \multicolumn{2}{|c|}{ Sectors of the catena } \\
\hline & & eluvial & accumulative \\
\hline & & \multicolumn{2}{|c|}{ Microrelief element of the microdepression } \\
\hline & & Micro-watershed & Bottom \\
\hline \multirow[t]{24}{*}{ 1. Holocene soil } & Horizon & Ah1 & Ah1 \\
\hline & Depth, cm & $0-50$ & $0-70$ \\
\hline & Color & Dark gray & Dark gray \\
\hline & Texture & Clay loam & Clay loam \\
\hline & Structure & Fine angular blocky-granular & Compound crumb-granular \\
\hline & Pedofeatures and inclusions & Bleached coarse silt & Bleached coarse silt \\
\hline & IPM & Homogeneous & Homogeneous \\
\hline & Boundary & Clear according to IPM color & Clear \\
\hline & Horizon & Ah2 & AhE \\
\hline & Depth, cm & $50-100$ & $70-110$ \\
\hline & Color & Brownish dark gray & Gray \\
\hline & Texture & Clay loam & Clay loam \\
\hline & Structure & Coarse-prismatic-columnar & $\begin{array}{l}\text { Compound angular blocky, in } \\
\text { the lower part angular blocky- } \\
\text { columnar }\end{array}$ \\
\hline & Pedofeatures and inclusions & $\begin{array}{l}\text { Dull humus-clay coatings overlain by } \\
\text { powdery carbonates }\end{array}$ & $\begin{array}{l}\text { Humus-clay coating overlain by } \\
\text { skeletans }\end{array}$ \\
\hline & IPM & Homogeneous & Homogeneous \\
\hline & Boundary & Clear & \\
\hline & Horizon & AhBk & AhEBt \\
\hline & Depth, cm & $100-170$ & $110-140$ \\
\hline & Color & Brown-gray & Gray-brown \\
\hline & Texture & Heavy loam & Heavy loam \\
\hline & Structure & $\begin{array}{l}\text { Compound, angular blocky-colum- } \\
\text { nar }\end{array}$ & $\begin{array}{l}\text { Compound, prismatic- coarse- } \\
\text { and fine-angular blocky }\end{array}$ \\
\hline & Pedofeatures and inclusions & $\begin{array}{l}\text { Powdery carbonates, whitish carbon- } \\
\text { ate films }\end{array}$ & $\begin{array}{l}\text { Abundant skeletans over dull } \\
\text { clay-humus coatings }\end{array}$ \\
\hline & IPM & Heterogeneous & Heterogeneous \\
\hline & Boundary & Disturbed by krotovinas & Clear \\
\hline \multirow{8}{*}{$\begin{array}{l}\text { 2. Late Valdai } \\
\text { loess }\end{array}$} & Horizon & BCk & Bt \\
\hline & Depth, cm & $170-210$ & $140-180$ \\
\hline & Color & Light brown & Brown \\
\hline & Texture & Silty clay loam & Clay loam \\
\hline & Structure & Columnar-prismatic & Prismatic-coarse-columnar \\
\hline & Pedofeatures and inclusions & Rare brown clay coatings & $\begin{array}{l}\text { Abundant skeletan over homus- } \\
\text { clay coatings }\end{array}$ \\
\hline & IPM & Homogeneous & Homogeneous \\
\hline & Boundary & Diffuse wavy with vertical veins & $\begin{array}{l}\text { Gradual } \\
\text { Diffuse }\end{array}$ \\
\hline
\end{tabular}


Table 1. (Contd.)

\begin{tabular}{|c|c|c|c|}
\hline \multirow{4}{*}{ Layer } & \multirow{4}{*}{ Parameter } & \multicolumn{2}{|c|}{ Sectors of the catena } \\
\hline & & eluvial & accumulative \\
\hline & & \multicolumn{2}{|c|}{ Microrelief element of the microdepression } \\
\hline & & Micro-watershed & Bottom \\
\hline \multirow{16}{*}{$\begin{array}{l}\text { 3. Bryansk } \\
\text { paleosol }\end{array}$} & Horizon & Ah & Ah \\
\hline & Depth, cm & $210-240$ & $180-250$ \\
\hline & Color & $\begin{array}{l}\text { Brownish-pale-yellow with gray } \\
\text { shade }\end{array}$ & Dark brown \\
\hline & Texture & Light clay & Light clay \\
\hline & Structure & Massive, ooidal & Massive \\
\hline & Pedofeatures and inclusions & Dark brown matte clay coatings & $\begin{array}{l}\text { Brown, clay, slightly gleyed coat- } \\
\text { ings }\end{array}$ \\
\hline & IPM & Heterogeneous, humified & \\
\hline & Boundary & $\begin{array}{l}\text { Pear-shaped core. The width of the } \\
\text { core in the upper part is } 50-60 \mathrm{~cm} \text {; } \\
\text { in the lower part, } 5-6 \mathrm{~cm} \text {; the height } \\
\text { is } 80-100 \mathrm{~cm}\end{array}$ & $\begin{array}{l}\text { Clay cores. Gradual } \\
\text { Diffuse }\end{array}$ \\
\hline & Horizon & AhB & AhBtb \\
\hline & Depth, cm & $210-290$ & $180-280$ \\
\hline & Color & Bright brown & Dark brown with grayish shade \\
\hline & Texture & Clay loam & Clay loam \\
\hline & Structure & Ooidal & Cloddy, ooidal \\
\hline & Pedofeatures and inclusions & $\begin{array}{l}\text { Ancient earthworm casts. Abundant } \\
\text { Mn-Fe concentrations, gleyed mot- } \\
\text { tles, calcitic tubules }\end{array}$ & $\begin{array}{l}\text { Dull brown coatings, tiny black } \\
\text { Mn nodules }\end{array}$ \\
\hline & IPM & Heterogeneous & Heterogeneous \\
\hline & Boundary & $\begin{array}{l}\text { Wedge-shaped. The height of wedges } \\
\text { is } 130-170 \mathrm{~cm} \text {, their width is } 100- \\
120 \mathrm{~cm} \text {. The distance between } \\
\text { wedges is } 100-150 \mathrm{~cm}\end{array}$ & $\begin{array}{l}\text { Gradual. } \\
\text { Diffuse. Wedges are hardly seen }\end{array}$ \\
\hline \multirow[t]{7}{*}{$3 a$} & Horizon & Bk of Bryansk paleosol & BCtg of Holocene chernozem \\
\hline & Depth, cm & $240-290$ & $240-280$ \\
\hline & Color & Light pale yellow & $\begin{array}{l}\text { Brownish pale yellow with blue- } \\
\text { gray shade }\end{array}$ \\
\hline & Texture & Silt loam & Silt loam \\
\hline & Pedofeatures and inclusions & $\begin{array}{l}\text { Loose carbonate accumulations. } \\
\text { Gleyed mottles and Mn concentra- } \\
\text { tions in the lower part }\end{array}$ & $\begin{array}{l}\text { Rare dull gleyed clay coatings. } \\
\text { Black Mn concentrations }\end{array}$ \\
\hline & IPM & Heterogeneous & Heterogeneous \\
\hline & Boundary & $\begin{array}{l}\text { Clear. Dark gray veins from the hori- } \\
\text { zon of Bryansk paleosol }\end{array}$ & $\begin{array}{l}\text { Gradual. } \\
\text { Diffuse }\end{array}$ \\
\hline
\end{tabular}


Table 1. (Contd.)

\begin{tabular}{|c|c|c|c|}
\hline \multirow{4}{*}{ Layer } & \multirow{4}{*}{ Parameter } & \multicolumn{2}{|c|}{ Sectors of the catena } \\
\hline & & eluvial & accumulative \\
\hline & & \multicolumn{2}{|c|}{ Microrelief element of the microdepression } \\
\hline & & Micro-watershed & Bottom \\
\hline \multirow{7}{*}{$\begin{array}{l}\text { 4. Early and Mid- } \\
\text { dle Valdai }\end{array}$} & Layer & Pedosediment & Pedosediment \\
\hline & Depth, cm & $290-350$ & $280-300$ \\
\hline & Color & $\begin{array}{l}\text { Grayish pale yellow with brownish } \\
\text { blue-gray shade }\end{array}$ & $\begin{array}{l}\text { Brownish pale yellow with blue- } \\
\text { gray shade }\end{array}$ \\
\hline & Texture & Silt loam & Silt loam \\
\hline & Pedofeatures and inclusions & $\begin{array}{l}\text { Mn-Fe concentrations, krotovinas, } \\
\text { blue-gray tiny carbonate nodules, } \\
\text { humified rusty veins }\end{array}$ & Rare Fe concentrations \\
\hline & IPM & Heterogeneous & Heterogeneous \\
\hline & Boundary & $\begin{array}{l}\text { Abrupt. Wavy with subvertical fis- } \\
\text { sures }\end{array}$ & Abrupt \\
\hline \multirow[t]{6}{*}{ 5. Moscow loess } & Layer & Loess & Loesslike, carbonate-free loam \\
\hline & Depth, cm & $\begin{array}{l}350-370 \text { (510 according to coring } \\
\text { data) }\end{array}$ & $300-370$ \\
\hline & Color & Whitish pale yellow & Light pale-yellow blue-gray \\
\hline & Texture & Sandy loam & Sandy loam \\
\hline & Pedofeatures and inclusions & $\begin{array}{l}\text { Mn-Fe concentrations, calcitic } \\
\text { tubules in pores }\end{array}$ & $\begin{array}{l}\text { Brown veins, rusty ferruginous } \\
\text { mottles, carbonate-free }\end{array}$ \\
\hline & IPM & Homogeneous & Heterogeneous \\
\hline
\end{tabular}

\section{Transitional Sector (Point $13 \mathrm{~m}$ ).}

In the middle of the trench, the slope of the depression begins (Fig. 3a, $10 \mathrm{~m}$, the beginning of the slope; Table 2). Thus, point $13 \mathrm{~m}$ is found in the transitional position toward the closed microdepression. On the slope with the slightly pronounced upper edge (points 9-10 m), the type of surface soil changes: Haplic Chernozem is replaced by Luvic Chernozem. In this sector of the catena, the humus profile of the modern soil is slightly shorter $(30-150 \mathrm{~cm}$ thick). The line of effervescence from a depth of $0.5 \mathrm{~cm}$ at point $9 \mathrm{~m}$ deepens to $150 \mathrm{~cm}$ at point $13 \mathrm{~m}$. A clay-illuvial horizon (Bt) appears between the humus and the carbonate-accumulative horizons. It can be traced on the trench wall starting from point $12 \mathrm{~m}$ in the form of a lens with bright brown ferruginous clayey coatings. The lower boundary of the clayey lens between points 12 and $13 \mathrm{~m}$ sharply drops down from 150 to $250 \mathrm{~cm}$. The Bt horizon represents a bright dark brown heavy loam of prismatic structure, porous, dense, carbonate-free, and disturbed by earth burrowers. The transition to the underlying Bryansk paleosol is gradual.

The Bryansk paleosol in this part of the catena is found at approximately the same depth $(200-220 \mathrm{~cm})$ and is also broken by cryogenic wedge-shaped struc- tures. However, on the slope, these structures acquire an irregular shape, become smaller, and the veins disappear (Fig. 3c). The material filling them has a darker color. The calcareous horizon of the Bryansk paleosol has a reddish tint. The clayey material inside the wedge-shaped structures is heterogeneous: it is less dense near boundary with the enclosing sediments and is denser in the central part; the inclusions are heterogeneous in density.

\section{Accumulative Sector (Point $16 \mathrm{~m}$ ).}

At the bottom of the microdepression, modern soil has a different morphology (Fig. 3a, from 13 to $19 \mathrm{~m}$, Tables 1 and 2).

Layer 1. Ah (A1), 0-70 cm. Dark gray heavy loam with well-shaped crumb-granular structure.

AhE (A1A2), 70-110 cm. Gray heavy loam; angular blocky structure in the upper part; angular blockycolumnar structure in the lower part; the IPM is of warm brownish color; humus-clay coatings on ped faces are covered by a skeletan with weakly manifested features of clay removal.

AhEBt (A2Bt), 110-140 cm. Gray-brown heavy loam; compound coarse prismatic aggregates parting 
Table 2. Comparison of the characteristics of modern soils and the Bryansk paleosol in different sectors of the catena (microrelief elements of the microdepression)

\begin{tabular}{|c|c|c|c|}
\hline \multirow{2}{*}{ Parameter } & \multicolumn{3}{|c|}{ Microrelief element of the microdepression } \\
\hline & microelevation & slope & bottom \\
\hline $\begin{array}{l}\text { Border of the sectors along } \\
\text { the profile, } m\end{array}$ & $1-10$ & $10-15$ & $15-19$ \\
\hline Holocene soil & Haplic Chernozems & Luvic Chernozems & Luvic Chernozems (Stagnic) \\
\hline Humus horizon Ah1 & Ah1 & Ah1 & Ah1 \\
\hline Second humus horizon Ah2 & Ah2 & $\mathrm{Ah} 2$ & $\mathrm{AhE}$ \\
\hline Transitional horizon AhB & AhB & $\mathrm{AhB} / \mathrm{AhBt}$ & $\begin{array}{l}\text { Transitional humus-eluvial-illuvial } \\
\text { horizon AhEBt }\end{array}$ \\
\hline Calcareous horizon Bk & $\mathrm{Bk}$ & $\mathrm{Bk} / \mathrm{Bt}$ & Illuvial horizon Bt \\
\hline Depth of humus profile, $\mathrm{m}$ & $1.5-1.95$ & $1.3-1.5$ & 1.4 \\
\hline $\mathrm{C}_{\text {org }}, \% \max$ & 9.2 & $10.3 / 9.9$ & Not determined \\
\hline $\mathrm{CO}_{2 \text { carb }}, \%$ & $6.5 / 5.6$ & 5.2 & 0 \\
\hline Late Valdai loess & Calcareous Ck & Carbonate-free & Carbonate-free loam \\
\hline Bryansk paleosol & Calcic Cambisol & & Gleyic Cambisol Gelistagnic \\
\hline Depth, m & $2.0 / 2.4$ & $2.0 / 2.2$ & $1.8 / 2.1$ \\
\hline Depth of the profile, $\mathrm{m}$ & $1.2-1.5$ & 1.0 & $0.8-1.1$ \\
\hline $\mathrm{Ah}$ & $\mathrm{Ah}$ & $\mathrm{Ah}$ & Aht \\
\hline $\mathrm{AhB}$ & AhBk & $\mathrm{AhB}$ & $\mathrm{AhBt}$ \\
\hline $\mathrm{Bt}$ & $\mathrm{Bk}$ & $\mathrm{Bk} / \mathrm{Bt}$ & Btg \\
\hline $\mathrm{C}_{\text {org }}, \% \max$ & $0.6-0.8$ & $0.7-0.8$ & $1.1-1.3$ \\
\hline $\mathrm{CO}_{2 \mathrm{carb}}, \%$ & 9.2 & $9.6-6.7 / 0.0$ & 0 \\
\hline
\end{tabular}

to fine angular blocky aggregates; abundant skeletans over clay-humus coatings on ped faces.

Layer 2. Valdai loess transformed into the Bt horizon, $140-180 \mathrm{~cm}$. Brown heavy loam of coarse prismatic-columnar structure, with abundant skeletans over humus-clay coatings covering the faces of large aggregates.

Layer 3. Bryansk paleosol, $180-280 \mathrm{~cm}$.

AhBtb ([ABT]). Grayish dark brown heavy loam; homogeneous; cloddy structure; ooidal microaggregation. Dull brown coatings on ped faces; fine black Mn nodules; wedge-shaped structures are poorly pronounced and represent diagenetically transformed humus horizon of the Bryansk paleosol [AhBt] with diffuse boundaries of dark brown color; the inner part of wedge-shaped structures has a heavier texture in comparison with the enclosing soil mass. Brown clayey slightly gleyed coatings on ped faces within the wedge-shaped structures are seen.

BCtg $(\mathrm{BTgC})$. Brownish pale yellow loam with bluish gray tint; porous, with both fine and coarse pores; blue-gray mottles and rusty veins are seen in this horizon. Few gleyed dull clayey coatings on ped faces. Black manganese concentrations are observed not only in pores but also in the IPM.
Layer 4. Pedosediment, 280-300 cm. Brownish yellow silt loam; finely porous, with filled pores and with few ferruginous concentrations.

Layer 5. Moscow loess, $300 \mathrm{~cm}$. Light yellow-gray sandy loam; heterogeneous in color, with numerous brown veins from layer 3; rusty ferruginous concentrations; does not effervesce; thin platy (post-schlieren) structure.

Soil horizons in the accumulative sector of the catena are not clearly distinguished because of weak color contrast. At the bottom of the microdepression, sediments are denser, have bright brown color, and are heavier in texture; they do not contain carbonates. The modern soil has a well-developed humus-accumulative horizon and morphologically distinct humus-eluvial (AhE), transitional (AhEBt), and illuvial (Bt) horizons. It is classified as Luvic Chernozem (Stagnic). In the bottom of the microdepression, the passages of burrowers are absent at the depth below 150$160 \mathrm{~cm}$ and are few in number in the overlying horizons. In general, at the bottom of the microdepression, the sediments are more homogeneous. The boundaries between the layers are diffuse.

Thus, Haplic Chernozems with the Ah1-Ah2$\mathrm{AhB}-\mathrm{Bk}-\mathrm{Ck}$ profile are formed on the microelevation in the eluvial sector of the catena, Luvic Cherno- 
zems with the Ah1-Ah2-AhB-Bt-Bk-Ck profile are formed on the slope in the transitional sector of the catena, and Luvic Chernozems (Stagnic) with the $\mathrm{Ah}-\mathrm{AhE}-\mathrm{AhB}-\mathrm{Bt}-\mathrm{C}$ profile are formed in the bottom of the microdepression in the accumulative sector of the catena.

The upper humus horizons are well developed in all soils within the catena and have approximately the same thickness. On the slope and in the bottom of the microdepression, the Ah2 subhorizon is replaced by the $\mathrm{AhE}$ horizon, and the Bk horizon is transformed into carbonate-free Bt horizon.

Micromorphological analysis. In the studied catena, the Ah horizon of the Holocene chernozem on the microelevation is characterized by the high mesofauna activity, abundant plant residues, granular microstructure with coprogenic aggregates, as well as peds of different sizes, and amorphous organic fine material (Fig. 4a). In the lower part of the Ah horizon and in the AhBk horizon, amorphous organic fine material is observed, the color is brown with black mottles; clear features of mesofauna activity, few coprogenic aggregates (Fig. 4b) and small $(<20 \mu \mathrm{m})$ round and elongated grains of lithogenic calcite are clearly seen in the soil mass. Ooidal microaggregates consisting of clayey-calcareous fine material are seen in the BCk horizon (Fig. 4c). Generally, fine material is not aggregated and contains little carbonates, but grains of lithogenic calcite are clearly seen in soil mass (Fig. 4c, arrows).

Holocene soils are superimposed over the Middle Valdai Bryansk paleosol and transform it differently in different sectors of the catena. At the microlevel, the Holocene diagenesis of the Ah horizon of the Bryansk paleosol seems to be minimal: fragmentation of the soil material by the mesofauna; this paleosol is rich in organic matter in the form of brown organomineral complexes (Fig. 4d). As the Bryansk paleosols developed from the Middle Valdai calcareous loess, elongated and rounded grains of lithogenic calcite immersed in the fine material can be found in all horizons of the paleosols. Moreover, sparite grains of probable biogenic origin are the largest in size, though they are few in number and are characterized by an unusual shape and appearance (Fig. 4e). Such grains can be found in all horizons of the Bryansk paleosol within the eluvial (elevation) part of the catena. Cryogenic sorting of quartz grains belonging to the Vladimir cryogenic horizon is clearly seen in the uppermost part of the Ah horizon of the Bryansk paleosol (Fig. 4f, arrows).

In Holocene soils on the slopes and in the bottom of the microdepression, in contrast to the microelevation, the Ah horizon has mainly amorphous brown organic matter. Another difference is less obvious signs of mesofauna activity (Fig. 5a). In the Bt horizon, there are visible features of waterlogging, such as gleyed mottles and iron nodules (Fig. 5b); fine material is anisotropic with cross-striated and granostriated orientation (Fig. 5c); carbonate material is observed only in the form of individual sparite grains in voids and as rounded and elongated lithogenic calcite grains scattered in fine material (Fig. 5c, arrows).

Clay material in the BCtg horizon of the Bryansk paleosol in the lower part of the catena (on the slopes and in the bottom of the microdepression) is strongly consolidated (porphyritic microfabric), with concentric striated, cross-striated, and granostriated orientation of fine material. Mineral grains are almost invisible and have the size of fine silt (Fig. 5d). Very thin iron-clay coatings are seen in the pores (Fig. 5e). Mottles of iron oxides are scattered within the soil material (Fig. 5d). Many black and sometimes translucent cube-shaped minerals (whewellite, weddellite?) that could be formed in voids of decayed plants and are a characteristic feature of this horizon (Fig. 5f).

In BCk horizon of the Bryansk paleosol at the bottom of the microdepression, there are few carbonate coatings in some pores (Fig. 5g). Sparite grains are extremely rarely observed in the soil material (Fig. 5h, arrows). In the lowest $\mathrm{BCkg}$ horizon, both undifferentiated carbonate nodules and ferruginous mottles are clearly visible (Fig. 5i, arrows).

Organic carbon and carbonates in the Bryansk paleosol: distribution along the catena. The depth to the Bryansk paleosol and its total thickness are relatively low and tend to decrease from the microelevation toward the bottom of the microdepression (Table 3); in the same direction, the soil texture becomes heavier.

The carbon content of organic matter varies significantly (for paleosols) along the catena: the lowest values are in the soil of the eluvial sector and the highest values are in the accumulative sector (two times higher than in the eluvial sector).

The carbonate content in the calcareous horizon of the Bryansk paleosol is greater than that in the calcareous horizon of the Holocene chernozem. It is the highest in the profile of the Bryansk soil in the eluvial sector of the catena and decreases sharply (up to trace levels) in the accumulative sector.

\section{DISCUSSION}

The Bryansk paleosol appears at a depth of 180$240 \mathrm{~cm}$ from the surface and even higher. On the microelevation, its position is the deepest; at the bottom of the microdepression, it is closer to the surface (Tables 1 and 2, Fig. 3).

Initially, the profile of the Bryansk paleosol probably consisted of the $\mathrm{Ah}-\mathrm{AhB}-\mathrm{Bk}-\mathrm{Bg}$ horizons. The thickness of the horizons was reconstructed: $\mathrm{Ah}$, no more than 5-10 cm; AhB, 20-30 cm; Bk, 25-40 cm; $\mathrm{Bg}, 10-20 \mathrm{~cm}$. The total thickness of the profile is $80-$ $100 \mathrm{~cm}$. This soil is less deep and less developed than modern soils of the studied region (chernozems). Such soil can be classified as interstadial soddy carbonateilluvial soil (Calcic Cambisol); at the final stages of its 

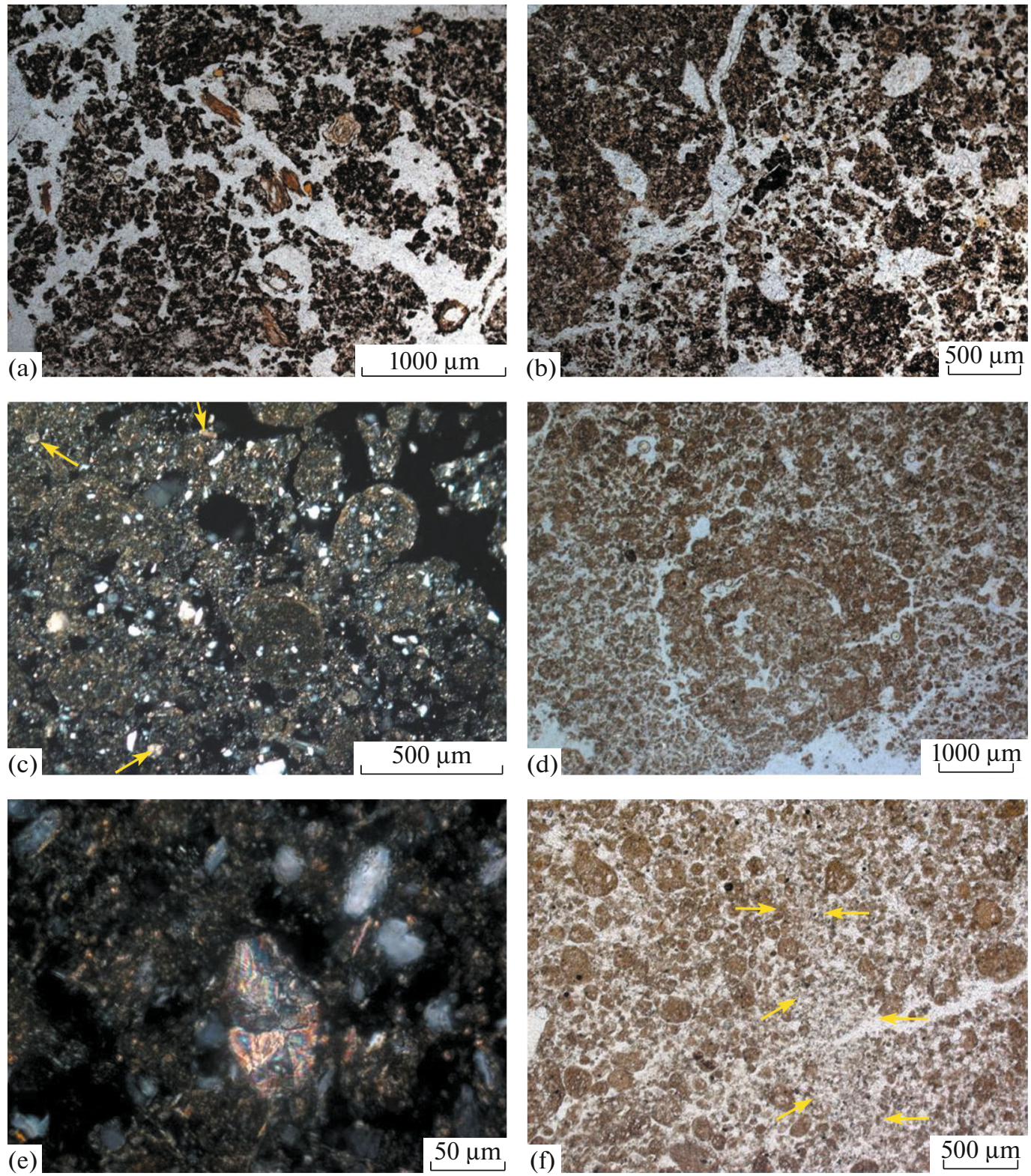

Fig. 4. Microfabrics of the Holocene soil and the Bryansk paleosol on the microelevation within the studied catena: (a) high degree of mesofauna activity, abundant plant residues, granular with coprogenic aggregates, peds of different sizes, amorphous organic fine material, upper part of the Ah horizon of the Holocene soil, PPL; (b) amorphous organic fine material, brown with black mottles, distinct signs of mesofauna activity, rare coprogenic aggregates, small $(<20 \mu \mathrm{m})$ grains of lithogenic calcite, lower part of Ah horizon of the Holocene soil, PPL; (c) ooidal microaggregates consisting of clay-carbonate fine material and dispersed grains of lithogenic calcite (arrows), BCk horizon, XPL; (d) fragmentation of the soil material by the mesofauna, abundance of organic matter in the form of brown organomineral complexes, Ah horizon of the Bryansk paleosol, PPL; (e) sparite grains, AhBk horizon of the Bryansk paleosol, XPL; (f) cryogenic sorting of quartz grains (arrows) in the upper part of the Ah horizon of the Bryansk paleosol, PPL.

development, as suprapermafrost gley soil (Calcic Cambisol (Gelistagnic)). The leading soil-forming processes were humus accumulation, argillization, illuviation of carbonates, and, at the final stages, significant cryoturbation and gleyzation. However, the diagnostic features of the Bryansk paleosol formed not only during pedogenesis (during the interstadial), but also in the subsequent climatic period (glacial maxi- mum), when the soil, still being on the surface, underwent significant changes $[20,36]$. The strongest cryogenesis at the maximum of the last glacial period (Vladimir cryogenic horizon) contributed to the significant redistribution of the main horizons of the Bryansk paleosol and their secondary gleyzation. As a result, the formation of cryogenic arrangement of a type of nonsorted circles led to disruption, dislocation, 

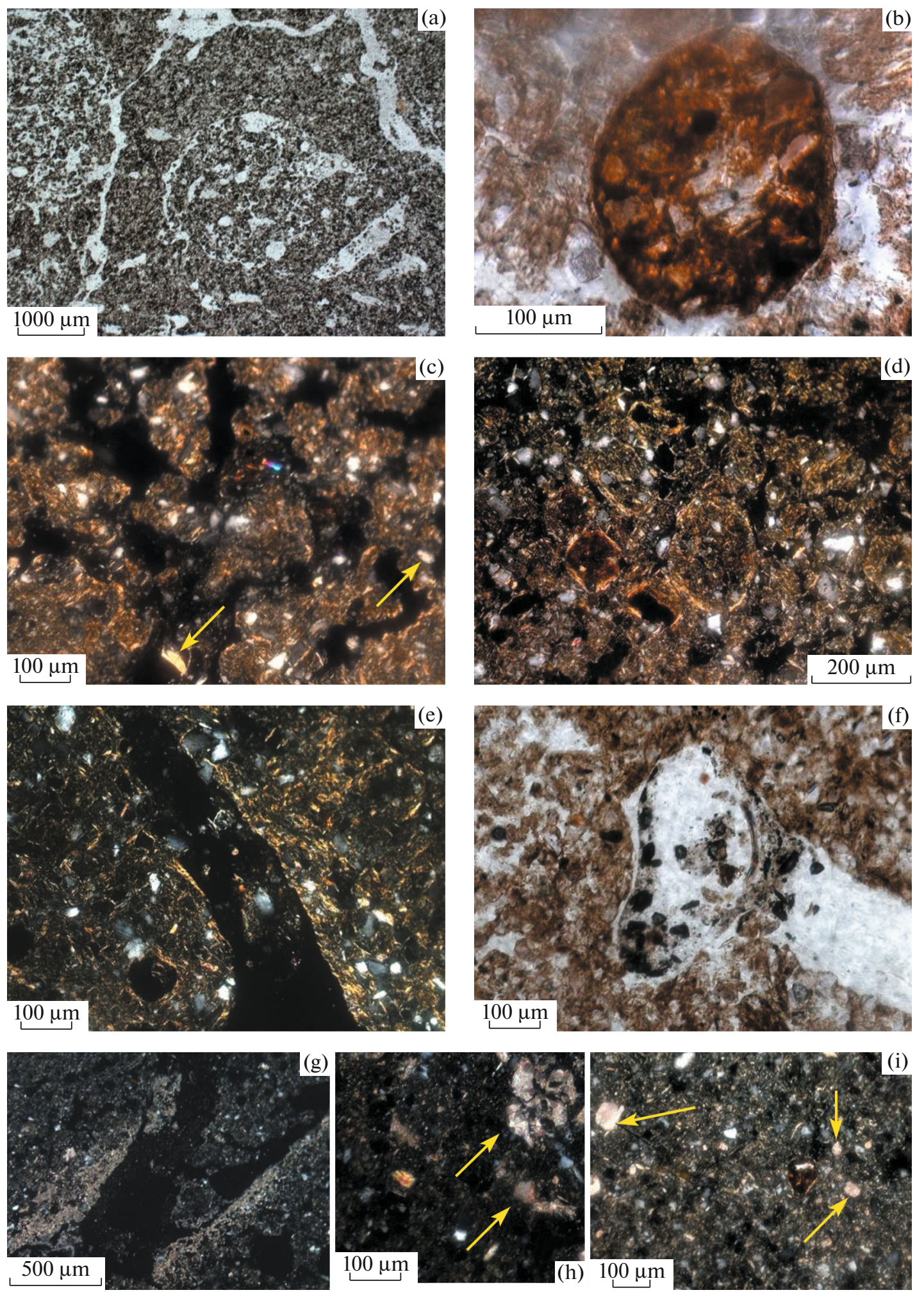

Fig. 5. Microfabrics of the Holocene soil and the Bryansk paleosol on the slopes and at the bottom of the microdepression: (a) brown amorphous organic fine material and weak indications of mesofauna activity, Ah horizon of the Holocene soil, PPL; (b) mottles and nodules of iron oxides (PPL); (c) cross-striated and granostriated orientation of fine material, individual sparite grains in pores and scattered rounded grains of lithogenic calcite (arrows) in fine material (XPL), Bt horizon of the Holocene soil; (d) highly compacted clayey material, porphyric microfabric, concentric striated and cross-striated orientation, mottles of iron oxides on the fine material, XPL; (e) thin Fe-clay coatings in the pores, XPL; (f) cube-shaped minerals (whewellite, weddellite?) formed in the voids of decayed plants, PPL; $(\mathrm{d}-\mathrm{f}) \mathrm{BCtg}$ horizon of the Bryansk paleosol (slope of the microdepression); (g) thin carbonate coatings, XPL, (h) sparite grains (arrows) in the soil material, XPL; (g-h) BCk horizon of the Bryansk paleosol; (i) undifferentiated carbonate nodules (arrows) and ferruginous mottles, BCkg horizon of the Bryansk paleosol, XPL. 
Table 3. The content of organic carbon and $\mathrm{CO}_{2}$ of carbonates in the Holocene and Bryansk soils in the catena across the microdepression in the Kazatskaya steppe

\begin{tabular}{|c|c|c|c|c|}
\hline Soil & Horizon & Depth, cm & $\mathrm{CO}_{2}, \%$ & Corg, $\%$ \\
\hline \multicolumn{5}{|c|}{ Pit at $1.5 \mathrm{~m}$ point, microelevation } \\
\hline Holocene & Bk & 170 & 5.6 & 0.65 \\
\hline \multirow[t]{4}{*}{ Bryansk } & Ah & 195 & 3.4 & 0.77 \\
\hline & Ah & 225 & 5.3 & 0.65 \\
\hline & Bk & 275 & 9.2 & 0.58 \\
\hline & Bk & 300 & 7.5 & 0.58 \\
\hline \multicolumn{5}{|c|}{ Pit at $5 \mathrm{~m}$ point, microelevation } \\
\hline Holocene & Bk & 200 & 5.1 & 0.60 \\
\hline \multirow[t]{3}{*}{ Bryansk } & AhBk & 240 & 4.1 & 0.60 \\
\hline & AhBk & 260 & 3.8 & 0.64 \\
\hline & AhBk & 285 & 2.5 & 0.60 \\
\hline \multicolumn{5}{|c|}{ Pit at $8 \mathrm{~m}$ point, microelevation } \\
\hline Holocene & $\mathrm{Bk}$ & 200 & 4.0 & 0.75 \\
\hline \multirow[t]{3}{*}{ Bryansk } & Ah & 220 & 4.0 & 0.92 \\
\hline & AhBk & 240 & 3.2 & 0.75 \\
\hline & $\mathrm{Bk}$ & 260 & 9.6 & 0.58 \\
\hline \multicolumn{5}{|c|}{ Pit at $13 \mathrm{~m}$ point, slope } \\
\hline \multirow[t]{2}{*}{ Holocene } & AhB & 140 & 0.0 & 1.12 \\
\hline & $\mathrm{Bt}$ & 150 & 0.0 & 0.68 \\
\hline \multirow[t]{10}{*}{ Bryansk } & $\mathrm{Ah}$ & 160 & 0.0 & 0.78 \\
\hline & $A h B$ & 180 & 1.0 & 0.62 \\
\hline & $A h B$ & 200 & 1.9 & 0.66 \\
\hline & $A h B$ & 220 & 1.9 & 0.66 \\
\hline & $A h B$ & 245 & 1.7 & 0.66 \\
\hline & $\mathrm{Ah}^{*}$ & 250 & 0.1 & 0.78 \\
\hline & $\mathrm{Ah}^{*}$ & 275 & 1.6 & 0.75 \\
\hline & Bk & 250 & 6.7 & 0.58 \\
\hline & Bk & 260 & 4.4 & 0.59 \\
\hline & Bk & 275 & 3.5 & 0.64 \\
\hline \multicolumn{5}{|c|}{ Pit at $17 \mathrm{~m}$ point, bottom } \\
\hline \multirow[t]{4}{*}{ Bryansk } & AhB & 200 & 0.0 & 1.10 \\
\hline & Ah & 220 & 0.0 & 1.27 \\
\hline & AhB & 240 & 0.0 & 1.07 \\
\hline & AhB & 260 & 0.0 & 0.99 \\
\hline
\end{tabular}

* Core samples were taken from the wedge-shaped structure of the Bryansk soil.

and displacement of soil horizons. The heavier loamy material of the humus horizon drained into the melted permafrost cracks formed pear-shaped cores of wedge-shaped structures (Fig. 3). The material of the AhB horizon filled wedge-shaped structures. The calcareous horizon was redeposited within interwedge spaces. As a result, in the profile of the Bryansk paleosol, many large wedge-shaped structures of 70$150 \mathrm{~cm}$ in width and $100-130$ to $180 \mathrm{~cm}$ in depth occur with an interval of $200-250 \mathrm{~cm}$.

The distribution of humus and carbonates in the Bryansk paleosol naturally changes along the catena. The humus content is higher $(1.10-1.27 \%)$ in the Ah horizon at the bottom of the microdepression (in the 
accumulative sector) than in the analogous horizon of the eluvial and transitional sectors $(0.75-0.78 \%)$. This is due not only to the initially higher humus content in the soils of the accumulative sector but also to its better conservation in the wetter conditions of the bottom of the depression. In the wet state, the soil organic matter mineralizes at a lower rate and is preserved for a longer time.

The carbonate content is higher in the Bk horizon of Bryansk paleosol than in the calcareous horizon of the Holocene chernozem. The carbonate content in the calcareous horizon of the Bryansk paleosol changes even more sharply along the catena. On the micro-elevation (eluvial sector), it has maximum values. A sharp decrease in its amount (up to the trace levels) in the accumulative sector is associated with leaching processes during the Holocene. At the bottom of the depression, carbonates are removed to a depth of more than $350 \mathrm{~cm}$.

Owing to cryoturbation of the profile (Ah horizon in the cores of ice wedges, AhB horizon in the wedgeshaped structures, and $\mathrm{Bk}$ horizon in the interwedge space), all three horizons of the Bryansk paleosol are located approximately at the same depth from the surface. Therefore, the calcareous horizon of modern chernozem on the microelevation can be superimposed over the humus, transitional, and even calcareous horizon of the Bryansk paleosol. In this case, the entire profile of the Bryansk soil is involved in modern soil formation, resulting in subhorizons with features of relict soils.

If the Bk horizon of the modern soil develops in the Valdai loess, a horizon of light brown color forms. However, if the calcareous horizon develops from the humus horizons of the Bryansk paleosol, then a grayish brown color mixes with the light brown color and $\mathrm{Ahkb}$ and AhBkb horizons are formed. First, they differ not only in color but also in different forms of carbonate pedofeatures. According to the analyses, the content of carbonates in the Ahkb and AhBkb horizons is lower than that in the compound calcareous horizon. In these horizons, carbonates tend to precipitate in well-developed coarse and medium pores as loose yellow masses. In the calcareous horizon of the Bryansk paleosol, which is much more porous than the Valdai loess, carbonate pedofeatures are more pronounced, and they are more evenly distributed in the loamy stratum. Owing to carbonate impregnation, the entire Bk horizon appears lighter. At the micro-scale, homogeneous carbonate impregnation of fine material is clearly seen, and there are carbonate pedofeatures specific for the Bryansk paleosol and represented by sparite grains of an unusual shape in the soil material; they attest to the high biogenic activity. The influence of the Vladimir cryogenic horizon is recognized by a distinct sorting of the coarse silicate material observed at the microscale.
An illuvial horizon of Luvic Chernozems already appears in the transitional sector. As a result of the eluvial-illuvial processes of Holocene pedogenesis, carbonates and even clay particles (as evidenced by clay coatings) and sesquioxides are removed from the profile of the Bryansk paleosol, which s observed both at the macro- and microlevels. At the microscale, anisotropic fine material is clearly seen, carbonates are represented as separate sparite grains in pores and lithogenic rounded grains scattered in the soil material.

In the accumulative sector, the profile of the Bryansk paleosol changes even more drastically. Owing to its position in the depression and its heavier texture, seasonal gleyzation is developed in this soil along with the processes of clay, $\mathrm{Fe}_{2} \mathrm{O}_{3}$, and $\mathrm{Al}_{2} \mathrm{O}_{3}$ illuviation. As a result, an illuvial-gley horizon develops in the lower part of the profile of the Bryansk paleosol. In this horizon, carbonate pedofeatures are in the form of undifferentiated dense small nodules, which are typical of wetter soil conditions.

Thus, two main stages of the Bryansk paleosol diagenesis have been identified:

1. Cryogenic deformation of the Bryansk paleosol. This stage occurred immediately after the functioning of the soil at the maximum of the Valdai glaciation (MIS 2). Cryoturbation (Vladimir cryogenic horizon) completely transformed the normal profile of the Bryansk soil. Due to the absence of burial for a long time, the soil carbon was constantly renewed, which led to the rejuvenation of the radiocarbon age of both carbonates and organic matter [36].

2. The secondary diagenesis of the Bryansk paleosol occurred under the influence of Holocene soil formation. The Bryansk paleosol that occurs at a shallow depth is part of the parent material of modern chernozems and soils of other genetic types. Owing to its occurrence at different depths, it is exposed to various soil-forming processes depending on the genesis of modern soil.

Secondary diagenesis may be relatively mild. Thus, in the eluvial sector of the catena, the entire profile of the Bryansk paleosol remained mainly untransformed, including the calcareous horizon (Figs. 3a and $3 b$ ). However, the secondary diagenesis might be very strong, as in the accumulative sector, where the soil profile and even the shape of cryogenic deformations were changed. They became oval with unclear diffuse boundaries (Figs. 3a and 3c).

The secondary diagenesis of the Bryansk paleosol is closely related to the genesis of depressions (closed saucer-like microdepressions). The anthropogenic genesis of microdepressions is excluded. For a long time, this territory has been the borderland of sedentary and nomadic peoples ("Wild Field"); it was poorly developed and never plowed up. This is confirmed by the absence of any anthropogenic turbulent disturbances both in the horizons of modern soils and in the layers of the loess-soil stratum. The absence of 
large post-cryogenic structures of the Yaroslavl cryogenic horizon (the Bryansk soil is developed not only on the microelevations but also on the slopes and at the bottom of the depressions) excludes the thermokarst origin of the microdepressions. The leading soil-geochemical processes are the secondary diagenetic transformation of the entire loess-soil stratum (carbonate removal, argillization, gleyzation, accumulation of $\mathrm{Fe}$, compaction), which attests to the suffosion-induced subsidence genesis of the studied depression.

\section{CONCLUSIONS}

The studied microdepression is of the suffosioninduced subsidence genesis. The Bryansk paleosol went through two main phases of diagenesis. The primary diagenesis took place during the maximum of the Valdai glaciation (MIS 2, Vladimir cryogenic horizon) and changed the normal profile of the Bryansk soil developed during the warm Middle Valdai interstadial (the final phase of MIS 3). The secondary diagenesis of the Bryansk paleosol is associated with the processes of Holocene soil formation. On the microelevation and in the upper part of the slope of the depression, the calcareous horizon of the Holocene chernozem is superimposed over the humus horizons of the Bryansk paleosol. In the lower part of the slope, carbonates are found deeper in the profile of Holocene soil. Carbonate-free zones appear in the profile of the Bryansk paleosol. At the bottom of the microdepression, the former calcareous horizon of the Bryansk soil is carbonate-free. The illuvial-clay horizon of the Holocene meadow chernozem is superimposed on the entire profile of the Bryansk soil. The profile becomes denser, and the structure changes. The peds of the Bryansk paleosol acquire an angular blocky structure and are covered with clay coatings, which were not typical of the Bryansk soil. That is, in the Holocene, the entire profile of the Bryansk soil turned into the illuvial horizon of Luvic Chernozems (Stagnic) due to leaching of carbonates and the illuviation of clay and sesquioxides.

\section{ACKNOWLEDGMENTS}

The authors are grateful to the administration and employees of the V.V. Alekhin Central Chernozemic Biospheric Reserve for the allowance of the trench digging in the reserved area.

\section{FUNDING}

The final part of the work, writing and preparation of the data for publication was supported by the Russian Foundation for Basic Research (project no. 19-29-05024mk). The physicochemical analyses were performed in the chemical laboratories of the Institute of Geography within the framework of state contract no. 0148-2019-0006. Micromorpho- logical analysis was performed on the equipment of the Collective Use Center of the Institute of Physicochemical and Biological Problems of Soil Science (Russian Academy of Sciences) within the framework of state contract no. 01912019-0046.

\section{CONFLICT OF INTEREST}

The authors declare that they have no conflict of interest.

\section{REFERENCES}

1. E. V. Arinushkina, Manual for the Chemical Analysis of Soils (Moscow State Univ., Moscow, 1970) [in Russian].

2. S. M. Bagrova and M. A. Korkka, "Paleosols of Bryansk interstadial of the Yamskaya steppe section (Belgorod oblast)," in Proceedings of XXIII International Scientific Conference of Students, Post-Graduate Students, and Young Scientists "Lomonosov-2016," Moscow, April 11-15, 2016 (MAKS Press, Moscow, 2016), pp. $49-50$.

3. A. B. Bogutskii, "Major 1 loess and paleosol horizons of periglacial loess-soil series of Pleistocene in the southwest of the East European Plain," in Stratigraphy and Correlation of Marine and Continental Deposits of Ukraine (Naukova Dumka, Kiev, 1987), pp. 47-52.

4. A. A. Velichko, "Development of cryogenic processes in the Upper Pleistocene," in Loess-Periglacial-Paleolith of Eastern and Central Europe, Ed. by I. P. Gerasimov (All-Union Institute of Scientific and Technical Information, Moscow, 1969), pp. 429-438.

5. A. A. Velichko and T. D. Morozova, "Bryansk fossil soil: stratigraphic role and natural conditions of formation," in Losses, Buried Soils, and Cryogenic Events in the Russian Plain (Nauka, Moscow, 1972), pp. 71-114.

6. N. P. Gerasimenko, Candidate's Dissertation in Geography (Kyiv, 2004).

7. M. I. Gerasimova, S. V. Gubin, and S. A. Shoba, Micromorphology of Soils of the Natural Zones of the Soviet Union (Pushchino Scientific Center, Pushchino, 1992) [in Russian].

8. N. I. Glushankova, Paleopedogenesis and the Environment of Eastern Europe in the Pleistocene (Madzhesta, Moscow, 2008) [in Russian].

9. Dynamics of Landscape Components and Internal Sea Basins of Northern Eurasia over the Last 130000 Years: Atlas-Monograph, Ed. by A. A. Velichko (GEOS, Moscow, 2002) [in Russian].

10. V. S. Zykina, Doctoral Dissertation in Geology-Mineralogy (Novosibirsk, 2006).

11. Classification and Diagnostics of Soils of the Soviet Union (Kolos, Moscow, 1977) [in Russian].

12. M. A. Korkka, A. V. Rusakov, S. M. Bagrova, and G. V. Rybin, "Morphology and pedostratigraphy of Holocene and Late Pleistocene soils (MIS5-MIS1) of the Yamskaya steppe section (Belgorod oblast)," in Proceedings of III All-Russian Scientific Conference with International Participation (KMK, Moscow, 2017), pp. 306-310. 
13. T. D. Morozova, Development of Soil Cover in Europe in the Late Pleistocene (Nauka, Moscow, 1981) [in Russian].

14. S. V. Naugol'nykh, "Paleosols of Upper Pleistocene in vicinities of Ramenskoe settlement (Moscow oblast): structure and possible interpretation," Byull. Kom. Izuch. Chetvertichn. Perioda, Akad. Nauk SSSR, No. 76, 84-98 (2018).

15. I. S. Olikova and S. A. Sycheva, "Water regime of virgin chernozems in the Central Russian Upland and its changes," Eurasian Soil Sci. 29, 582-590 (1996).

16. S. A. Sycheva, "Paleocryogenic events in the periglacial region of the Russian Plain at the end of the Middle and in Late Pleistocene," Kriosfera Zemli 16 (4), 45-56 (2012).

17. S. A. Sycheva, "Buried Mikulinsko-Valdai relief and development of interfluves of the Central Russian Upland in the Late Neopleistocene," Geomorfologiya, No. 1, 88-105 (2007).

18. S. A. Sycheva, Candidate's Dissertation in Geography (Institute of Geography, Academy of Sciences of the Soviet Union, Moscow, 1979).

19. S. A. Sycheva, "The evolution of the balka system in the climatic cycle glaciation-interglacial period-glaciation," Geomorfologiya, No. 2, 100-111 (1997).

20. S. A. Sycheva, S. N. Sedov, and O. S. Khokhlova, "Bryansk paleosol of Central Russian Upland: ${ }^{14} \mathrm{C}$ age, duration, and evolution history," Byull. Kom. Izuch. Chetvertichn. Perioda, Akad. Nauk SSSR, No. 74, 5368 (2015).

21. A. I. Tsatskin, Candidate's Dissertation in Geography (Institute of Geography, Academy of Sciences of the Soviet Union, Moscow, 1980) [in Russian].

22. O. A. Chichagova, Radiocarbon Dating of Soil Humus (Nauka, Moscow, 1985) [in Russian].

23. P. Antoine, D. D. Rousseau, M. Fuchs, C. Hatte, C. Gauthier, S. Markovic, M. Jovavic, T. Gaudeny, O. Moine, and J. Rossignol, "High-resolution record of the last climatic cycle in the southern Carpathian basin (Surduk, Voijvodina, Serbia)," Quat. Int. 37, 66-73 (2008)

24. P. Antoine, D.-D. Rousseau, L. Zoller, A. Lang, A. V. Munaut, C. Hatte, and M. Fortugne, "High-resolution record of the last interglacial-glacial cycle in the Nussloch loess-paleosol sequences, Upper Rhine area, Germany," Quat. Int. 76-77, 211-299 (2001).

25. N. Gerasimenko, "Upper Pleistocene climatic variations in Ukraine recorded by loess-paleosol and vegetational successions," GeoLines 11, 86-89 (2000).

26. M. Frechen, B. van Vliet-Lanoe, and P. van den Haute, "The Upper Pleistocene loess record at Harmignies/Belgium-high resolution terrestrial archive of climate forcing," Palaeogeogr., Palaeoclimatol., Palaeoecol. 173, 175-195 (2011).

27. P. Havlíček and L. Smolikova, "Vývoi syrchno pleistocenní cheolických sedimentůve Znojmě-Dřevařskýchzá. The development of the Upper Pleistocene eolian sediments in Znojmo-lumber works," Věstn. Čeck. Geol. Ústavu 70 (1), 67-74 (1995).
28. IUSS Working Group WRB, World Reference Base for Soil Resources 2014, International Soil Classification System for Naming Soils and Creating Legends for Soil Maps, World Soil Resources Reports No. 106 (UN Food and Agriculture Organization, Rome, 2014).

29. R. Kołodyńska-Gawrysiak, J. Chodorowski, P. Mroczek, A. Plak, W. Zgłobicki, A. Kiebała, J. Trzciński, and K. Standzikowski, "The impact of natural and anthropogenic processes on the evolution of closed depressions in loess areas. A multi-proxy case study from Nałẹczów Plateau, Eastern Poland,” Catena 149, 1-18 (2017).

30. R. Kołodyńska-Gawrysiak and J. Poesen, "Closed depressions in the European loess belt-Natural or anthropogenic origin?" Geomorphology 288, 111-128 (2017).

31. K. Konescka-Betley, "Fossil soils of Late Pleistocene developed from loesses," Rocznikigleboznavcze 44, 55-62 (1994).

32. Proceedings of the 7th Loess Seminar and 6-Day Loess Fieldtrip in Poland "Kukla LOESSFEST'14," Abstracts of Papers, Ed. by Z. Jary and P. Mroczek (Wroclaw, 2014).

33. A. Rusakov, S. Sedov, V. Sheinkman, D. Dobrynin, E. Zinovyev, S. Trofimova, F. Maksimov, V. Kuznetsov, M. Korkka, and S. Levchenko, "Late Pleistocene paleosols in the extra-glacial regions of northwestern Eurasia: pedogenesis, post-pedogenic transformation, paleoenvironmental inferences,” Quat. Int. 501, 174-192 (2019).

34. S. N. Sedov, O. S. Khokhlova, A. A. Sinitsyn, M. A. Korkka, A. V. Pusakov, B. Ortega, M. S. Rozanova, A. M. Kuznetsova, and A. A. Kazdumh, "Late Pleistocene paleosol sequence as an instrument for the local paleogeographic reconstruction of the Kostenki 14 key section (Voronezh oblast) as an example," Eurasian Soil Sci. 43, 876-892 (2010).

35. S. Sedov, A. Rusakov, V. Sheinkman, and M. Korkka, "MIS3 paleosols in the center-north of Eastern Europe and Western Siberia: reductomorphic pedogenesis conditioned by permafrost?" Catena 146, (2016).

https://doi.org/10.1016/j.catena.2016.03.022

36. S. A. Sycheva and O. S. Khokhlova, "Genesis ${ }^{14} \mathrm{C}$ age, and duration of development of the Bryansk paleosol on the Central Russian Upland based on dating of different materials," Quat. Int. 399, 111-121 (2016). https://doi.org/10.1016/j.quaint.2015.08.055

37. B. Terhorst, Ch. Thiel, R. Peticzka, T. Sprafke, M. Frechen, F. A. Fladerer, R. Roetzel, and Ch. NeugebauerMaresch, "Casting new light on the chronology of the loess/paleosol sequences in Lower Austria, Eiszeitalter und Gegenwart," Quat. Sci. J. 60, 270-277 (2011).

38. T. H. van Andel, "The climate and landscape of middle part of Weichselian glaciation in Europe: the stage 3 project," Quat. Res. 57, 2-8 (2002).

39. T. H. van Andel and P. C. Tzedakis, "Palaeolithic landscapes of Europe and Environs, 150.000-25.000 years ago: an overview," Quat. Sci. Rev. 15, 481-500 (1996).

Translated by D. Konyushkov 